\title{
Effect of Nitrogen, Location, and Harvesting Stage on Peppermint Productivity, Oil Content, and Oil Composition
}

\author{
Valtcho D. Zheljazkov ${ }^{1}$ and Vasile Cerven \\ Mississippi State University, North Mississippi Research and Extension \\ Center, 5421 Highway 145 South, Verona, MS 38879
}

Charles L. Cantrell

Natural Products Utilization Research Unit, Agricultural Research Service, U.S. Department of Agriculture, P.O. Box 8048, University, MS 38677

Wayne M. Ebelhar

Delta Research and Extension Center, P.O. Box 197, Stoneville, MS 38776

\author{
Thomas Horgan \\ Mississippi State University, North Mississippi Research and Extension \\ Center, 5421 Highway 145 South, Verona, MS 38879
}

Additional index words. Mentha $\times$ piperita, essential oil, composition

\begin{abstract}
Peppermint (Mentha $\times$ piperita) is currently not a common crop in the southeastern United States. Recently, there has been an interest in peppermint as an essential oil crop for this region. In 2007, a field experiment was conducted in Mississippi to determine the effect of nitrogen $(N)\left(0\right.$ and $\left.80 \mathrm{~kg} \cdot \mathrm{ha}^{-1}\right)$, location (Verona and Stoneville), and harvesting stage (bud formation and flowering) on peppermint productivity, oil content, and composition. Peppermint biomass yields were higher at Verona $\left(8.12 \mathrm{t} \cdot \mathrm{ha}^{-1}\right)$ than at Stoneville $\left(6.12 \mathrm{t} \cdot \mathrm{ha}^{-1}\right)$. However, the essential oil content was higher at Stoneville $(1.1 \%)$ than at Verona $(0.6 \%)$. Generally, $N$ rate at $80 \mathrm{~kg} \cdot \mathrm{ha}^{-1}$ did not affect oil yield and composition compared with $0 \mathrm{~kg} \cdot \mathrm{ha}^{-1}$. The concentrations of the major essential oil constituents were: (-)-menthol at $26 \%$ to $30 \%$, (-)-menthone at $14 \%$ to $21 \%$, $(+)$-menthofuran at $5 \%$ to $11 \%$, and eucalyptol at $3 \%$ to $4 \%$ of total essential oil (wt/wt) and were generally within the values previously reported. The concentrations of (-)-menthone and (+)-menthofuran were significantly higher at Stoneville, $21 \%$ and $11 \%$, respectively, than at Verona $(14 \%$ and $6 \%)$. The (-)-menthol, (-)-menthone, and $(+)$-menthofuran yields/ha were higher at Stoneville than at Verona. Overall oil content and yields were higher at bud formation than at flowering, 1.3 and 1.8 times, respectively. In addition, the concentration of (-)-menthone and eucalyptol and the yields of (-)-menthone, $(+)$-menthofuran, and eucalyptol were higher at bud formation than at flowering. The results from this study demonstrated peppermint can be successfully grown in Mississippi and provide essential oil yields and composition comparable to those in the northwestern United States, the traditional peppermint-growing region.
\end{abstract}

Peppermint is an aromatic plant grown for essential oil production, which is a major aromatic agent. Peppermint is also grown for production of dry leaves, which are used in

Received for publication 12 Mar. 2009. Accepted for publication 17 Apr. 2009.

Contribution of the Mississippi Agricultural and Forestry Exp. Sta. journal article No J-11560.

This research was funded by ARS Specific Coop. Agreement 58-6402-4-026 with CRIS MIS-027100. Specific project: "Field Establishment of Medicinal Herbs and Potential for Commercial Production" awarded to Dr. Zheljazkov.

We thank Marie Rogers for her help in the field and laboratory, Amber Callahan for her help with quantitative analysis, and Dr. D. Rowe for help with the statistical analysis.

${ }^{1}$ To whom reprint requests should be addressed; e-mailvj40@pss.msstate.edu. herbal teas. The essential oil is used in a number of consumer products such as chewing gum, toothpaste, mouthwashes, in pharmaceuticals, confectionary, and aromatherapy (Mint Industry Research Council, 2009). The major oil-producing countries include Bulgaria, England, France, Hungary, Italy, Moldova, Romania, Russia, and Yugoslavia in Europe, China, and India in Asia, and the United States. Peppermint has been grown in the northwestern United States for over 100 years. Peppermint oil production in the United States for 2006 was estimated at $3289 \mathrm{t}$ per year from a harvested area of $\approx 32,076$ ha (USDA, NASS, Crop Report, 2007). The U.S. peppermint oil is considered of high quality and U.S. essential oil broker companies have dominated the peppermint essential oil market.
The essential oil content and composition of peppermint are important economically for producers, processors, manufacturers of peppermint-containing products, and for consumers. Prior research has shown that environmental factors such as harvest date and photoperiod (Clark and Menary, 1979a, 1979b), latitude and growing conditions (Topalov, 1962), soil contamination (Zheljazkov et al., 2006; Zheljazkov and Nielsen, 1996), soil amendments (Zheljazkov, 2005; Zheljazkov and Warman, 2004), and agronomic practices such as harvest stage (Clark and Menary, 2006), irrigation (Nedkov and Georgiev, 1991; Ram et al., 1995; Topalov, 1962), pesticide application (Zheljazkov and Margina, 1996), or fertilization (Mitchell and Farris, 1996; Scavroni et al., 2005; Topalov, 1962) influence peppermint essential oil content and composition. The climate in the northwestern United States is considered suitable for the production of high-quality peppermint essential oil. As a result of the decline of peppermint growing areas in the northwestern United States recently (because of expanding corn acreage for ethanol production and other factors), there is a need and an interest toward the establishment of peppermint as a high-value essential oil crop in the southeastern United States. However, there are no reports on peppermint productivity, essential oil content, and composition in Mississippi or in the southeastern United States. The hypothesis was that peppermint can be grown in the Mississippi climate and its productivity and oil composition would be similar to mint grown in other regions or countries. The goal of this project was to investigate the possibility for production of peppermint in Mississippi. The objective was to evaluate the effect of nitrogen $(\mathrm{N})$, location, and harvesting stage on peppermint productivity, oil content, and composition. This is the first study on peppermint as an essential oil crop for Mississippi and the southeastern United States.

\section{Materials and Methods}

Plant material and growing conditions. The experiment was conducted in the 2007 cropping season at two locations in Mississippi: the North Mississippi Research and Extension Center at Verona (long. 34 43' 22" N, lat. $-88^{\circ} 43^{\prime} 22^{\prime \prime}$ W) and the Delta Research and Extension Center in Stoneville (long. 33 $25^{\prime} 18^{\prime \prime} \mathrm{N}$, lat. $-90^{\circ} 54^{\prime} 28^{\prime \prime} \mathrm{W}$ ). Soil samples were taken before land preparation and analyzed for nutrient availability using the Lancaster soil test method (Cox, 2001). The concentration of nutrients in soil extracts was measured using an inductively coupled argon plasma spectrometer (Perkin Elmer, Norwalk, CT) at the Mississippi State University Soil Testing and Plant Analysis Laboratory.

In early spring, the land was disked and raised beds were formed using the Press bed shaper machine (Kennco Manufacturing, Inc., Ruskin, FL). The machine also placed a drip-tape irrigation tube in the soil $\approx 5 \mathrm{~cm}$ 
deep with the emitters facing up. The beds were $15 \mathrm{~cm}$ high and $75 \mathrm{~cm}$ wide across the top. Each individual experimental plot was $6.1 \mathrm{~m}$ long and had 40 plants in two rows with $0.3 \mathrm{~m}$ in the row and between-row spacing. Virus-free elite plant material of peppermint (Mentha piperita L.) 'Black Mitcham' was purchased from the Summit Plant Laboratories (Fort Collins, CO). This is the traditional cultivar that has been used for over 100 years for peppermint oil production in the United States. Peppermint transplants were planted the first week of May at Verona and Stoneville. Before planting, the sites were treated with herbicide Sinbar $(80 \%$ terbacil) at 2 $\mathrm{kg} \cdot \mathrm{ha}^{-1}$ (preplant-incorporated) and the herbicide Roundup (glyphosate; Monsanto, St. Louis, MO) at 1.5\% on 27 Apr. 2007.

The experiment was conducted on Prentiss fine sandy loam at Verona and on Bosket very fine sandy loam at Stoneville. Although the soil at Stoneville had higher organic matter than the soil at Verona (Table 1), both soil types contain relatively low organic matter compared with organic matter content of most well-drained mineral surface soils (Brady and Weil, 2008). The soil pH at the two sites was very similar and slightly acidic, but the concentration of available nutrients was dissimilar at the two sites (Table 1). Phosphorus (P) and potassium (K) fertilizers were applied at rates of $79 \mathrm{~kg} \mathrm{P} / \mathrm{ha}$ and $103 \mathrm{~kg}$ $\mathrm{K} /$ ha to the two sites before land preparation. The experiment was a completely randomized design with four replicates. The $\mathrm{N}$ fertilizers were surface-applied on experimental plots by hand. The treatments at the two locations were: (1) N fertilizers (at $0 \mathrm{~N}$ $\mathrm{kg} \cdot \mathrm{ha}^{-1}$ of control and $80 \mathrm{~N} \mathrm{~kg} \cdot \mathrm{ha}^{-1}$ ); and (2) harvesting stages (bud formation and flowering stage). There were 16 research plots at each location. Peppermint was harvested by hand at bud formation or at flowering stage by cutting plants $\approx 10 \mathrm{~cm}$ above the soil surface. The edge plants were removed. The whole plots were harvested; fresh and dry biomass yields were measured and recorded. Representative subsamples from each plot were steam-distilled for essential oil content and composition.

Essential oil extraction and gas chromatography-mass spectrophotometer analyses. Before distillation, all peppermint samples were air-dried in shade. Essential oils were extracted from $250 \mathrm{~g}$ air-dried plant material (stems, leaves, and flowers) for $1 \mathrm{~h}$ distillation time by steam distillation on a modified Clevenger collector apparatus (Hearthmagic, Rancho Santa Fe, CA) using

Table 1. Selected initial soil characteristics $(0$ to $15 \mathrm{~cm})$ and the concentration of extractable nutrients in the soil at two locations.

\begin{tabular}{|c|c|c|c|c|c|c|c|c|c|}
\hline \multirow{2}{*}{$\begin{array}{l}\text { Location, } \\
\text { soil type }\end{array}$} & $\mathrm{OM}$ & $\mathrm{pH}$ & Phosphorus & Potassium & Calcium & Magnesium & Zinc & Sulfur & Sodium \\
\hline & $(\%)$ & \multicolumn{8}{|c|}{$\left(\mathrm{kg} \cdot \mathrm{ha}^{-1}\right)$} \\
\hline Stoneville & 1.37 & 6.1 & 101 & 230 & 2,005 & 113 & 1.8 & 221 & 96 \\
\hline $\begin{array}{l}\text { Bosket very } \\
\text { fine sandy loam }\end{array}$ & & & & & & & & & \\
\hline $\begin{array}{l}\text { Verona } \\
\text { Prentiss fine } \\
\text { sandy loam }\end{array}$ & 1.11 & 6.0 & 146 & 320 & 3,172 & 535 & 3.8 & 179 & 103 \\
\hline
\end{tabular}

a 2.0-L distillation system (Furnis et al., 1989). The plant material was chopped into pieces $\approx 2$ to $3 \mathrm{~cm}$ long before distillation. Peppermint essential oil from each treatment was weighed, and the oil yield was calculated as the weight $(\mathrm{g})$ of oil per weight $(\mathrm{g})$ of dry peppermint tissue.

Chemical standards and the peppermint oil from each plot were analyzed by gas chromatography-mass spectrophotometry on a Varian CP-3800 gas chromatograph coupled to a Varian Saturn 2000 mass spectrophotometer/mass spectrophotometer (Palo Alto, CA). The gas chromatograph was equipped with a DB-5 fused silica capillary column $(30 \mathrm{~m} \times 0.25 \mathrm{~mm}$ with film thickness of $0.25 \mu \mathrm{m}$ ) operated using the following conditions: injector temperature, $240{ }^{\circ} \mathrm{C}$, column temperature 60 to $240{ }^{\circ} \mathrm{C}$ at $3{ }^{\circ} \mathrm{C}$ / min then held at $240{ }^{\circ} \mathrm{C}$ for $5 \mathrm{~min}$; carrier gas, helium; injection volume, $1 \mu \mathrm{L}$ (splitless). The mass spectrophotometry mass ranged from 40 to $650 \mathrm{~m} / \mathrm{z}$, filament delay of $3 \mathrm{~min}$, target total ion chromatogram (TIC) of 20,000 , a prescan ionization time of 100 $\mu \mathrm{sec}$, an ion trap temperature of $150{ }^{\circ} \mathrm{C}$, manifold temperature of $60^{\circ} \mathrm{C}$, and a transfer line temperature of $170{ }^{\circ} \mathrm{C}$.

Quantitative analysis. Commercial standards (-)-menthol, (-)-menthone, (+)-menthofuran, and eucalyptol were purchased from Fluka (Buchs, Switzerland). With five concentration points, an external standard least squares regression for quantification was used. All four analytes were used to formulate separate calibration curves. All calculations were performed by the generation of standard curves within Varian's Saturn gas chromatography-mass spectrophotometry Workstation software package Version 6.40. The chromatograms of each of the oils from the field experiments were compared with the standard injections. The target peaks were confirmed by both retention time and mass spectral data. Confirmed integrated peaks were then used to determine the percentage of each chemical constituent in the essential oil. We have quantified only the four major peppermint oil constituents (-)-menthol, (-)-menthone, (+)-menthofuran, and eucalyptol, because they comprise more than $75 \%$ of the oil and are the major constituents modifying oil quality.

Statistical analysis. Analysis of variance and correlation coefficients were executed with the Proc Mixed Procedure and Proc COOR Procedure (SAS Institute, 2003). The significance of treatments were determined at $P=0.05$ level of significance.

\section{Results and Discussion}

For the peppermint harvested at flowering, biomass yields were greater at Verona than at Stoneville; however, essential oil content and (-)-menthol yields were higher at Stoneville (Table 2). Also at flowering, (-) -menthone and (+)-menthofuran concentrations and yield/ha were higher at Stoneville than at Verona, whereas eucalyptol concentrations and yields were unaffected by location (Table 2). Nitrogen at $80 \mathrm{~kg} \cdot \mathrm{ha}^{-1}$ did not affect biomass yields, oil content, or the concentration or yield of the oil constituents compared with $0 \mathrm{~kg} \cdot \mathrm{ha}^{-1}$ (Table 2).

Peppermint harvested at bud formation had a greater oil content and yield per area than at flowering (Table 3). Nitrogen at $80 \mathrm{~kg} \cdot \mathrm{ha}^{-1}$ did not affect peppermint oil or (-)-menthol concentrations and yields when harvested at bud formation compared with $0 \mathrm{~kg} \cdot \mathrm{ha}^{-1}$ (Table 3 ). In addition, at bud formation, oil content and yields were higher at Stoneville than at Verona, but (-)-menthol content and yields were not different at the two locations. Oil yields at both locations were higher from peppermint harvested at bud formation than at flowering (Table 3 ) as a result of higher biomass yields at bud formation. Oil content, (-)-menthol content, and yields within location were unaffected by harvesting stage or by $\mathrm{N}$ application rate at $80 \mathrm{~kg} \cdot \mathrm{ha}^{-1}$. The concentration of (-)-menthone was higher at flowering, but because of greater biomass yield at bud formation, the overall (-)-menthone yield was greater at bud formation (Table 3). The concentration of $(+)$-menthofuran was unaffected by harvesting stage, but because of the difference in biomass yields, the overall $(+)$-menthofuran yields were greater at bud formation (Table 3). Overall, $\mathrm{N}$ rate at $80 \mathrm{~kg} \cdot \mathrm{ha}^{-1}$ did not affect (-)-menthone and menthofuran concentration or yields compared with $0 \mathrm{~kg} \cdot \mathrm{ha}^{-1}$.

Overall, the concentration and the yield of (-)-menthone and the yield of (+)-menthofuran were greater at Stoneville than at Verona (Table 3). Within a location, (-) -menthone concentration and yield were greater at bud formation than at flowering. The overall (+)-menthofuran yields were unaffected by harvesting stage within a location, although $(+)$-menthofuran concentrations were different as a result of harvesting stage (Table 3). At bud formation within each of the locations, $\mathrm{N}$ application rate at 80 $\mathrm{kg} \cdot \mathrm{ha}^{-1}$ did not affect (-)-menthone and $(+)$-menthofuran concentrations or yields. Eucalyptol concentration and yields were higher at bud formation than at flowering (Table 3). Generally, eucalyptol concentration and yields were unaffected by $\mathrm{N}$ application rate at $80 \mathrm{~kg} \cdot \mathrm{ha}^{-1}$. Eucalyptol yield was greater at Stoneville than at Verona. Within location (either Stoneville or Verona), eucalyptol yields were greater at bud formation than at flowering (Table 3).

It has been reported that the essential oil accumulation in peppermint could be influenced by environmental factors such as photoperiod (Clark and Menary, 1979b), 
Table 2. Effect of location and nitrogen rate on peppermint biomass yield, essential oil, and composition at flowering stage.

\begin{tabular}{|c|c|c|c|c|c|c|c|c|c|c|c|c|c|}
\hline \multirow[b]{2}{*}{ Effect } & \multirow[b]{2}{*}{ Location } & \multirow[b]{2}{*}{$\begin{array}{c}\text { N rate } \\
\left(\mathrm{kg} \cdot \mathrm{ha}^{-1}\right)\end{array}$} & \multirow{2}{*}{$\begin{array}{c}\text { Biomass } \\
\text { yield } \\
\left(\mathrm{t} \cdot \mathrm{ha}^{-1}\right)\end{array}$} & \multicolumn{2}{|c|}{ Essential oil } & \multicolumn{2}{|c|}{ (-)-Menthol } & \multicolumn{2}{|c|}{ (-)-Menthone } & \multicolumn{2}{|c|}{$(+)$-Menthofuran } & \multicolumn{2}{|c|}{ Eucalyptol } \\
\hline & & & & $\begin{array}{c}\text { Content }^{\mathrm{z}} \\
(\%)\end{array}$ & $\begin{array}{c}\text { Yield } \\
\left(\mathrm{kg} \cdot \mathrm{ha}^{-1}\right)\end{array}$ & $\begin{array}{c}\text { Concn }^{y} \\
(\%)\end{array}$ & $\begin{array}{c}\text { Yield } \\
\left(\mathrm{kg} \cdot \mathrm{ha}^{-1}\right)\end{array}$ & $\begin{array}{c}\text { Concn }^{\mathrm{y}} \\
(\%)\end{array}$ & $\begin{array}{c}\text { Yield } \\
\left(\mathrm{kg} \cdot \mathrm{ha}^{-1}\right)\end{array}$ & $\begin{array}{c}\text { Concn }^{y} \\
(\%)\end{array}$ & $\begin{array}{c}\text { Yield } \\
\left(\mathrm{kg} \cdot \mathrm{ha}^{-1}\right)\end{array}$ & $\begin{array}{c}\text { Concn }^{\mathrm{y}} \\
(\%)\end{array}$ & $\begin{array}{c}\text { Yield } \\
\left(\mathrm{kg} \cdot \mathrm{ha}^{-1}\right)\end{array}$ \\
\hline Location & Stoneville & & $6.12 \mathrm{~b}^{\mathrm{x}}$ & $1.1 \mathrm{a}$ & 66.8 & 28.8 & $19.0 \mathrm{a}$ & $20.8 \mathrm{a}$ & $13.8 \mathrm{a}$ & $10.7 \mathrm{a}$ & $7.2 \mathrm{a}$ & 4.4 & 6.5 \\
\hline Location & Verona & & $8.12 \mathrm{a}$ & $0.62 \mathrm{~b}$ & 48.9 & 26.7 & $13.3 \mathrm{~b}$ & $14.2 \mathrm{~b}$ & $7.2 \mathrm{~b}$ & $5.7 \mathrm{~b}$ & $3.0 \mathrm{~b}$ & 3.1 & 6.1 \\
\hline $\mathrm{N}$ rate & & 0 & 6.58 & 0.87 & 54.2 & 28.8 & 15.7 & 17.3 & 9.7 & 7.5 & 4.3 & 3.6 & 6.5 \\
\hline $\mathrm{N}$ rate & & 80 & 7.65 & 0.85 & 61.5 & 26.7 & 16.5 & 17.7 & 11.2 & 8.9 & 5.9 & 3.9 & 6.1 \\
\hline Location $* \mathrm{~N}$ rate & Stoneville & 0 & 5.48 & 1.12 & 61.5 & 29.8 & 18.2 & 21 & 12.9 & 9.6 & 5.9 & 4 & 6.5 \\
\hline Location ${ }^{*} \mathrm{~N}$ rate & Stoneville & 80 & 6.75 & 1.09 & 72.1 & 27.7 & 19.8 & 20.6 & 14.7 & 11.7 & 8.5 & 4.7 & 6.5 \\
\hline Location $* \mathrm{~N}$ rate & Verona & 0 & 7.68 & 0.62 & 46.9 & 27.7 & 13.3 & 13.6 & 6.5 & 5.3 & 2.6 & 3.1 & 6.5 \\
\hline Location $* N$ rate & Verona & 80 & 8.56 & 0.61 & 50.9 & 25.7 & 13.2 & 14.9 & 7.8 & 6.1 & 3.4 & 3.1 & 5.7 \\
\hline \multicolumn{3}{|c|}{ Analysis of variance } & \multicolumn{5}{|c|}{$P$ values } & & & & & & \\
\hline Location & & & 0.0135 & 0.0046 & 0.1032 & 0.1623 & 0.0466 & 0.0013 & 0.0007 & 0.0001 & 0.0003 & 0.0963 & 0.1966 \\
\hline $\mathrm{N}$ rate & & & 0.1698 & 0.8307 & 0.3865 & 0.1636 & 0.7528 & 0.7802 & 0.3899 & 0.0692 & 0.1096 & 0.6244 & 0.162 \\
\hline Location*N ra & & & 0.7987 & 0.9117 & 0.6916 & 0.994 & 0.7328 & 0.5393 & 0.9152 & 0.433 & 0.4004 & 0.5506 & 0.1844 \\
\hline
\end{tabular}

${ }^{\mathrm{z}}$ Essential oil content was calculated as grams of oil per $100 \mathrm{~g}$ of dry peppermint biomass.

${ }^{\mathrm{y}}$ The concentration of menthol, menthone, menthofuran, and eucalyptol is percent of the total amount of the peppermint essential oil.

${ }^{x}$ Means within columns and within a treatment followed by different letters are significantly different at $P<0.05$.

Table 3. Effect of harvesting stage on peppermint oil and on the concentration and yield of essential oil constituents.

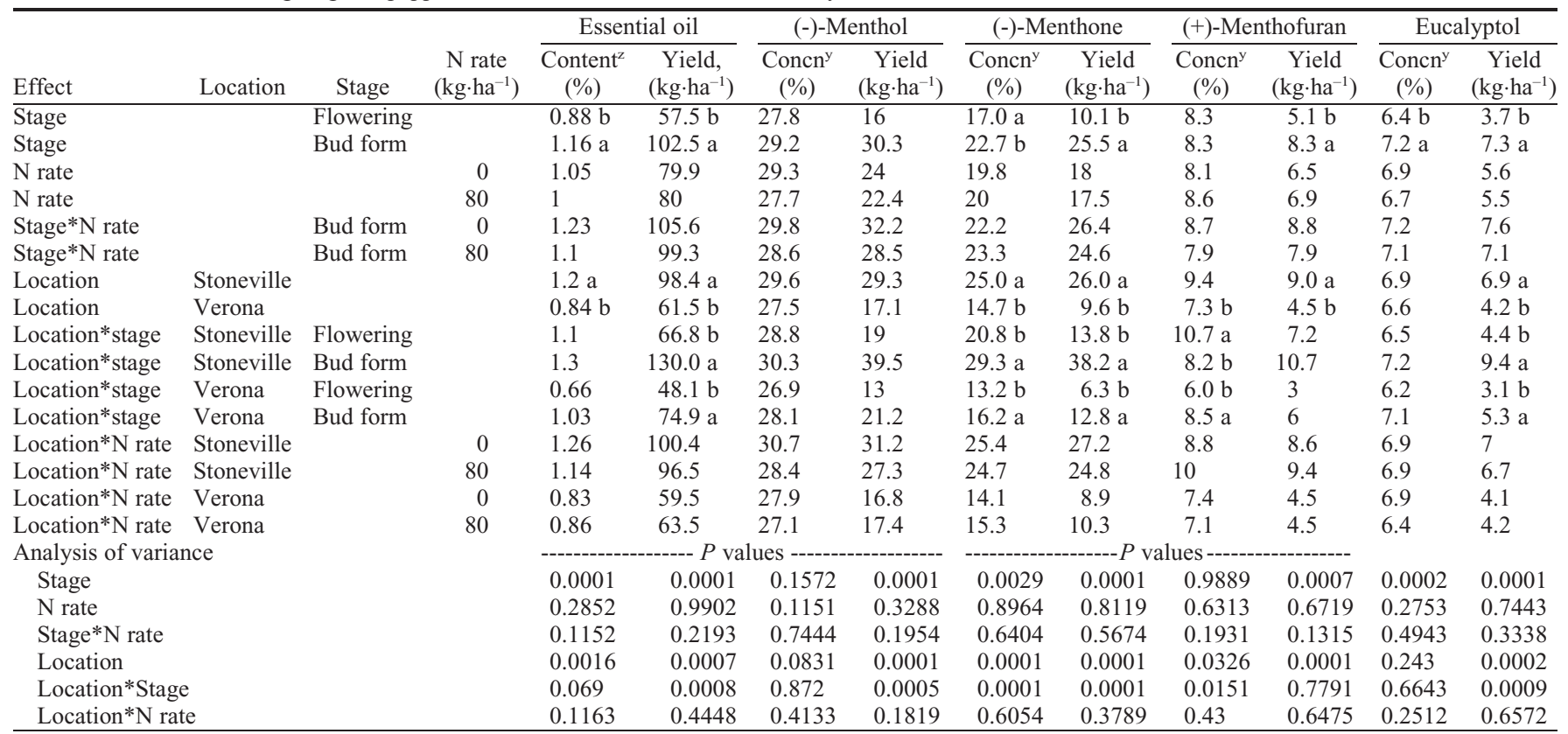

${ }^{\mathrm{z}}$ Essential oil content was calculated as grams of oil per $100 \mathrm{~g}$ of dry peppermint biomass.

${ }^{\mathrm{y}}$ The concentration of menthol, menthone, menthofuran, and eucalyptol is percent of the total amount of the peppermint essential oil.

temperature (Clark and Menary, 1980a, 1980b), light (Burbott and Loomis, 1967), and agronomic factors such as soil amendments, nutrients, or trace elements (Alkire and Simon, 1995; Mustiatse, 1985; Nedkov and Georgiev, 1991; Scavroni et al., 2005; Zheljazkov, 2005; Zheljazkov and Margina, 1996; Zheljazkov and Nielsen, 1996). Nitrogen is one of the most important modifiers of peppermint productivity and oil composition (Clark and Menary, 1980c; Jeliazkova et al., 1999; Kothari and Singh, 1995; Mitchell and Farris, 1996; Piccaglia et al., 1993; Singh et al., 1989). Generally, higher N application rates were associated with high biomass yields. The lack of $\mathrm{N}$ response in our study may be attributable (1) to the residual $\mathrm{N}$ in the soil at the two locations; (2) to the relatively low $\mathrm{N}$ application rate $\left(80 \mathrm{~kg} \cdot \mathrm{ha}^{-1}\right)$; and (3) the variability within the experiment, which might have masked the response to N. Further research with higher $\mathrm{N}$ application rates may be needed to establish optimal $\mathrm{N}$ and other fertilizer requirements of peppermint in the southeastern United States.

Timing of the harvest is important with respect to oil yield and composition (Clark and Menary, 2006; Marcum and Hanson, 2006; Marotti et al., 1993; Rohloff et al., 2005; Zheljazkov, 1998) and with respect to the overall economics (Mint Industry Research Council, 2009). Generally, our results confirm previous reports regarding the effect of location and harvest stage on peppermint biomass yields, oil content, and composition (Clark and Menary, 2006; Marcum and Hanson, 2006; Rohloff et al., 2005; Zheljazkov, 1998). In the northwestern United States, and in other countries, peppermint is usually harvested at the flowering stage (Clark and Menary, 1979a, 2006; Marcum and Hanson, 2006; Marotti et al., 1993; Rohloff et al., 2005; Zheljazkov, 1998) when the (-)-menthol concentration of the oil is the highest and the concentrations of (-)-menthone and $(+)$-menthofuran are decreasing. We have observed a similar trend in this study in Mississippi. However, harvesting at bud formation may provide a possibility for a second harvest (cut) under Mississippi climate, which is not generally possible in the northwestern United States. A second cut of peppermint could significantly improve the overall economics of the crop. In our experiment, biomass yields, oil content, and yields were greater at bud formation than at flowering. A possible explanation is that after bud formation, when the temperatures are high (which is the case in Mississippi but not in the northwestern United States), peppermint starts losing some the older leaves on the lower branches. These older leaves carry most of the (-)-menthol and essential oil (Mustiatse, 1985; Zheljazkov, 1998), which subsequently results in lower oil yields after bud formation in the Mississippi climate. The concentration of (-)-menthol is supposed to increase with delay in harvesting (Zheljazkov, 1998); however, in our experi- 
ment, (-)-menthol concentration and yields were not different at flowering and at bud formation. In addition to the loss of older leaves, higher night temperatures in Mississippi relative to the northwestern United States may promote higher respiration rates and ultimately lower than expected (-)-menthol accumulation. Generally, the concentration of (-)-menthol in our study is comparable to lower values for this monoterpene reported in the literature. However, comparison with the literature data is not easy, because in most reports, (-)-menthol was reported as area under the curve out of the $100 \%$, which are qualitative data, whereas we did an absolute quantification of (-)-menthol, and the other constituents, in this study. As expected, the concentrations of (-)-menthone and $(+)$-menthofuran in our study were higher at bud formation than at flowering. The (-)-menthone is a precursor for (-)-menthol, whereas $(+)$-menthofuran is a side product of (-)-menthone synthesis from (+)-pulegone (Mahmoud and Croteau, 2003; Rios-Estepa et al., 2008). In high-quality peppermint oil, $(+)$-menthofuran is expected to be at a relatively low concentration (Mahmoud and Croteau, 2003; Topalov, 1962). Further research is needed to identify suitable agronomic and environmental factors that may reduce the concentration of (-)-menthone and $(+)$-menthofuran and increase the concentration of (-)-menthol in peppermint oil in Mississippi. This is the first report on peppermint as an essential oil crop and the first direct quantification of major essential oil constituents of peppermint as a function of $\mathrm{N}$ application rate, production location, and harvesting stage in the southeastern United States. Overall, this preliminary study demonstrated that peppermint can be grown as an essential oil crop in Mississippi and possibly other regions throughout the southeastern United States.

\section{Conclusions}

This preliminary work at two locations has demonstrated that location and harvesting stage had significant effects on peppermint oil yields. Peppermint essential oil yields were maximized at bud formation. Location and harvesting stage had significant effects on the concentrations and the yields of the major peppermint oil constituents. The range of the quantified concentrations of peppermint oil constituents under the Mississippi climate were: (-)-menthol at $26 \%$ to $30 \%,(-)-$ menthone at $14 \%$ to $21 \%,(+)$-menthofuran at $5 \%$ to $11 \%$, and eucalyptol at $3 \%$ to $4 \%$ of total essential oil. Overall, peppermint biomass yields, oil content and oil yields, and the concentrations of the major oil constituents in this study were similar to those found in the literature. This study demonstrated peppermint can be successfully grown as an essential oil crop in Mississippi and possibly the southeastern United States.

\section{Literature Cited}

Alkire, B.H. and J.E. Simon. 1995. Response of Midwestern peppermint (Mentha pipperita L.) and native spearmint (M. spicata $\mathrm{L}$.) to rate and from of nitrogen fertilizer. Acta Hort. 426:537549.

Brady, N.C. and R.R. Weil. 2008. The nature and properties of soils. 14th Ed. Pearson-Prentice Hall, Upper Saddle River, NJ.

Burbott, A.J. and W.D. Loomis. 1967. Effects of light and temperature on the monoterpenes of peppermint. Plant Physiol. 42:20-28.

Clark, R.J. and R.C. Menary. 1979a. The importance of harvest date and plant density on the yield and quality of Tasmanian peppermint oil. J. Amer. Soc. Hort. Sci. 104:702-706.

Clark, R.J. and R.C. Menary. 1979b. Effects of photoperiod on the yield and composition of peppermint oil. J. Amer. Soc. Hort. Sci. 104:699-702.

Clark, R.J. and R.C. Menary. 1980a. Environmental effects on peppermint (Mentha piperita L.). I. Effect of day length, photon flux density, night temperature and day temperature on the yield and composition of peppermint oil. Aust. J. Plant Physiol. 7:685-692.

Clark, R.J. and R.C. Menary. 1980b. Environmental effects on peppermint (Mentha piperita L.). II. Effects of temperature on photosynthesis, photorespiration and dark respiration in peppermint with reference to oil composition. Aust. J. Plant Physiol. 7:693-697.

Clark, R.J. and R.C. Menary. 1980c. The effect of irrigation and nitrogen on the yield and composition of peppermint oil (Mentha pipperita L.). Aust. J. Agr. Res. 31:489-498.

Clark, R.J. and R.C. Menary. 2006. The effect of two harvests per year on the yield and composition of Tasmanian peppermint oil (Mentha piperita L.). J. Sci. Food Agr. 35:1191-1195.

Cox, M.S. 2001. The Lancaster soil test method as an alternative to the Mehlich 3 soil test method. Soil Sci. 166:484-489.

Furnis B.S., A.J. Hannaford, P.W.G. Smith, and A.R. Tatchell. 1989. Vogel's textbook of practical chemistry. 5th Ed Longman Scientific \& Technical, New York, NY. p. 171-175.

Jeliazkova, E.A., V.D. Zheljazkov, L.E. Craker, B. Yankov, and T. Georgieva. 1999. NPK fertilizer and yields of peppermint, Mentha $\times$ piperita. Acta Hort. 502:231-236.

Kothari, S.K. and U.B. Singh. 1995. The effect of row spacing and nitrogen fertilization on scotch spearmint (Mentha gracilis Sole). J. Essent. Oil Res. 7:287-297.

Mahmoud, S.S. and R.B. Croteau. 2003. Menthofuran regulates essential oil biosynthesis in peppermint by controlling a downstream monoterpene reductase. Proc. Natl. Acad. Sci. USA 100:14481-14486.

Marcum, D.B. and B.R. Hanson. 2006. Effect of irrigation and harvest timing on peppermint oil yield in California. J. Agr. Water Mgt. 82:118128.

Marotti, M., V. Dellacecca, R. Piccaglia, and E. Giovanelli. 1993. Effect of harvesting stage on the yield and essential oil composition of peppermint (Mentha xpiperita L.). Acta Hort. 344:370-379.
Mint Industry Research Council. 2009. Feb. 2009. $<$ http://usmintindustry.org/>.

Mitchell, A.R. and N.A. Farris. 1996. Peppermint response to nitrogen fertilizer in an arid climate. J. Plant Nutr. 19:955-967.

Mustiatse, G.I. 1985. Kultura miaty perechnoi (peppermint). Stiintsa, Chisinau, Moldova. p. 140.

Nedkov, N.K. and G.V. Georgiev. 1991. A study of different irrigation practices used for Mentha piperita in Bulgaria. J. Essent. Oil Res. 3:435440.

Piccaglia, R., V. Dellacecca, M. Marotti, and E. Giovanelli. 1993. Agronomic factors affecting the yields and the essential oil composition of the peppermint (Mentha $\times$ pipperota L.). Acta Hort. 344:29-40.

Ram, M., D. Ram, and S. Singh. 1995. Irrigation and nitrogen requirements of Bergamot mint on a sandy loam soil under sub-tropical conditions. J. Agr. Water Mgt. 27:45-54.

Rios-Estepa, R., G.W. Turner, J.M. Lee, R.B. Croteau, and B.M. Lange. 2008. A systems biology approach identifies the biochemical mechanisms regulating monoterpenoid essential oil composition in peppermint. Proc. Natl. Acad. Sci. USA 105:2818-2823.

Rohloff, J., S. Dragland, R. Mordal, and I. TorHenning. 2005. Effect of harvest time and drying method on biomass production, essential oil yield and quality of peppermint (Mentha $\times$ piperita L.). J. Agr. Food Chem. 53:41434148.

SAS Institute. 2003. SAS for Windows. Version 9.1.3. SAS Inst., Cary, NC.

Scavroni, J., C.S.F. Boaro, M.O.M. Marques, and L.C. Ferreira. 2005. Yield and composition of the essential oil of Mentha piperita L. (Lamiaceae) grown with biosolid. Braz. J. Plant Physiol. 17:345-352.

Singh, V.P., B.N. Chatterjee, and D.V. Singh. 1989. Response of mint species to nitrogen fertilization. J. Agr. Sci. 113:267-271.

Topalov, V.D. 1962. Mentha, p. 106-153. In: Topalov, V.D. (ed.). Essential oil and medicinal plants. Hr. G. Danov Press, Plovdiv, Bulgaria.

USDA-NASS, Crop Report. 2007. Jan. 2009. $<$ http://www.nass.usda.gov/Statistics_by_State/ Oregon/Publications/Field_Crop_Report/crop $\% 20$ reports/01_12cr.pdf $>$.

Zheljazkov, V. and A. Margina. 1996. Effect of increasing doses of fertilizer application on quantitative and qualitative characters of mint. Acta Hort. 426:579-584.

Zheljazkov, V.D. 1998. Mentha species, p. 304310. In: Phehlivanor, M., G. Moskov, B. Jankov, J. Terziev, V. Zheljazkov. and H. Yantcheva (eds.). Plant production edition 1. Academic edition of Higher Institute of Agriculture, Plovdiv, Bulgaria.

Zheljazkov, V.D. 2005. Assessment of wool-waste and hair-waste as soil amendment and nutrient source. J. Environ. Qual. 34:2310-2317.

Zheljazkov, V.D., L.E. Craker, and B. Xing. 2006. Effects of $\mathrm{Cd}, \mathrm{Pb}$, and $\mathrm{Cu}$ on growth and essential oil contents in dill, peppermint, and basil. Environ. Exp. Bot. 58:9-16.

Zheljazkov, V.D. and N.E. Nielsen. 1996. Effect of heavy metals on peppermint and cornmint. Plant Soil 178:59-66.

Zheljazkov, V.D. and P.R. Warman. 2004. Application of high-Cu compost to dill and peppermint. J. Agr. Food Chem. 52:2615-2622. 